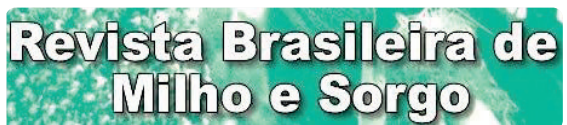

Brazilian Journal of Maize and Sorghum

ISSN 1980 - 6477

Journal homepage: www.abms.org.br/site/paginas

Bianca Braz Mattos ${ }^{(1)}$, Ivanildo Evódio Marriel ${ }^{(2)}$ Sylvia Morais de Sousa ${ }^{(2)}$, Ubiraci Gomes de Paula Lana ${ }^{(2)}$, Robert Eugene Schaffert ${ }^{(2)}$, Eliane Aparecida Gomes ${ }^{(2)}(\bowtie)$ and Christiane Abreu de Oliveira $^{(2)}(\bowtie)$

Embrapa Solos, Rio de Janeiro, RJ, Brazil

E-mail: bianca.mattos@embrapa.br

(2) Embrapa Milho e Sorgo, Sete Lagoas, MG, Brazil

E-mail: ivanildo.marriel@embrapa.br,

sylvia.sousa@embrapa.br,

ubiraci.lana@embrapa.br,

robert.schaffert@embrapa.br,

eliane.a.gomes@embrapa.br,

christiane.paiva@embrapa.br.

$\varangle$ Corresponding author

How to cite

MATTOS, B. B.; MARRIEL, I. E.; SOUSA S. M.; LANA, U. G. P.; SCHAFFERT, R. E. GOMES, E. A.; OLIVEIRA, C. A. Sorghum genotypes response to inoculation with phosphate solubilizing bacteria. Revista Brasileira de Milho e Sorgo, v. 19, e1177, 2020.

\section{SORGHUM GENOTYPES RESPONSE TO INOCULATION WITH PHOSPHATE SOLUBILIZING BACTERIA}

\begin{abstract}
Sorghum bicolor adapts to phosphorus (P) deficient soils through mechanisms that contribute to its absorption and solubilization, including the association with microorganisms. The direct application of rock phosphate (RP) and the inoculation with phosphate solubilizing bacteria (PSB) is a sustainable alternative for P supply to the crops. The aim of this study was to evaluate the effect of PSB inoculation of two sorghum genotypes with different P responses (BR007 - efficient and responsive and SC283 - efficient and non-responsive), cultivated in soil fertilized with RP and triple superphosphate (TSP), in greenhouse and field experiments. The sorghum genotypes were inoculated separately with the Bacillus strains that are efficient in $\mathrm{P}$ solubilization, B116 and B70, and cultivated under different $\mathrm{P}$ fertilization sources (TSP, $\mathrm{RP}, 1 / 2 \mathrm{TSP}+1 / 2 \mathrm{RP})$. The results suggest that the inoculation response was dependent on sorghum genotype, P source and microbial strain. Inoculation of the genotype BR007 significantly increased root biomass and grain $\mathrm{P}$ content under greenhouse conditions, as well as yield and grain P content in field experiments, but no effect was observed on genotype SC283. The use of PSB as bioinoculants, in combination with RP, is a promising alternative to reduce the use of synthetic fertilizers, contributing to the sustainable sorghum production.
\end{abstract}

Keywords: Plant growth-promoting bacteria (PGPB); fertilization; rock phosphate; rhizosphere bacteria; Sorghum bicolor.

\section{RESPOSTA DE GENÓTIPOS DE SORGO À INOCULAÇÃO COM BACTÉRIAS SOLUBILIZADORAS DE FOSFATO}

Resumo - Sorghum bicolor adapta-se a solos deficientes em fósforo (P) por meio de mecanismos que contribuem para sua absorção e solubilização, incluindo a associação com microrganismos. A aplicação direta de fosfato de rocha (FR) e a inoculação com bactérias solubilizadoras de fosfato (BSP) é uma alternativa sustentável para o suprimento de $\mathrm{P}$ para as culturas agrícolas. O objetivo deste estudo foi avaliar o efeito da inoculação com BSP de dois genótipos de sorgo com diferentes respostas a $\mathrm{P}$ (BR007 - eficiente e responsivo e SC283 - eficiente e não responsivo), cultivados em solo fertilizado com FR e superfosfato triplo (ST), em ensaios de casa de vegetação e campo. Os genótipos de sorgo foram inoculados separadamente com as estirpes de Bacillus eficientes na solubilização de P, B116 e B70, e cultivados em diferentes fontes de fertilização fosfatadas (ST, FR, $1 / 2 \mathrm{ST}+1 / 2 \mathrm{FR}$ ). Os resultados sugerem que a resposta à inoculação depende do genótipo de sorgo, da fonte de $\mathrm{P}$ e da estirpe microbiana. A inoculação do genótipo BR007 aumentou significativamente o acúmulo de biomassa e seu conteúdo de $\mathrm{P}$ em casa de vegetação, além da produção e teor de $\mathrm{P}$ nos grãos em campo, mas nenhum efeito foi observado no genótipo SC283. O uso de BSP como bioinoculantes, em combinação com o FR, é uma alternativa promissora para reduzir o uso de fertilizantes sintéticos, contribuindo para a produção sustentável de sorgo.

Palavras-chave: bactéria promotora do crescimento de plantas (BPCP); fertilização; fosfato de rocha; bactérias rizosféricas; Sorghum bicolor. 
Food production should increase by $70 \%$ in a 30-year projection due to the world population growth (FAO, 2018). In this scenario, the current agricultural output of 2.1 billion tons per year will need to grow to more than 3 billion to meet the global demand (FAO, 2018). Brazil needs to invest in sustainable strategies to continue advancing in the production of crops adapted to abiotic and biotic stresses, based on sustainable management practices, alternative nutrient sources and association with microorganisms.

Sorghum [Sorghum bicolor (L.) Moench] is an important source of food, feed and forage, being fundamental for food security and sustainable livelihoods in developing countries (Mareya et al., 2019). Despite its remarkable ability to adapt to different environments and resistance to diseases and pests, sorghum producers often face constraints that affect grain yield caused by drought and poor soil fertility (Schaffert et al., 2001).

Low phosphorus (P) availability in the soil is one of the limiting factors for grain yield in tropical regions. In order to increase yield and reduce $\mathrm{P}$ deficiency, farmers frequently use synthetic fertilizers at high rates, causing environmental impacts on soil structure, composition and microbial community. In addition, Brazil imports most of the phosphate fertilizers, which limits crop production for smallholder farmers (Withers et al., 2018). Thus, direct application of naturally occurring and less expensive rock phosphate (RP) is an alternative for an environmentally friendly and sustainable
P supply. However, crude RP presents low solubility and it is not readily available to the plants or agronomically effective when applied directly to soils. Thereby, some alternatives have been studied to increase the solubility of this $\mathrm{P}$ source, making its use even more attractive, such as the use of phosphate solubilizing bacteria (PSB) as biofertilizers. An enhanced $\mathrm{P}$ acquisition after PSB inoculation has been reported in several crops, including wheat (Emami et al., 2019), pearl millet (Ribeiro et al., 2018), maize (Venkatesha et al., 2019; Sousa et al., 2020), and sorghum (Ehteshami et al., 2018).

Sorghum inoculated with two P-solubilizing fungi and fertilized with RP increased P uptake, shoot dry matter yield and plant height, under controlled conditions (Steiner et al., 2016). However, sorghum response to the inoculation with PSB can differ depending on plant genotype, microorganism strain, soil and climate conditions (Ehteshami et al., 2018; Schlemper et al., 2018). The objective of this work was to evaluate, under greenhouse and field conditions, the effect of two P solubilizing bacteria on plant development, $\mathrm{P}$ accumulation and grain yield of two sorghum genotypes with different $\mathrm{P}$ responsiveness (BR007 - efficient and responsive to $\mathrm{P}$ and SC283 - efficient and nonresponsive to $\mathrm{P}$ ), cultivated on soil fertilized with RP in the presence and absence of triple superphosphate (TSP). 


\section{Material and Methods}

Sorghum genotypes and bacterial inoculant

\section{preparation}

Two sorghum genotypes (SC283 and BR007), with different $\mathrm{P}$ responsiveness, belonging to the Embrapa Milho e Sorgo Breeding Program, were evaluated. They were chosen from a subset of the association panel described by Casa et al. (2008) with 287 accessions, comprising both tropical converted and breeding accessions, based on an evaluation under low P-soil for grain yield and for root system morphology and architecture in hydroponics (Hufnagel et al., 2014). SC283 has higher grain yield under low-P availability compared to BR007, while grain yield is higher in BR007 than SC283 under adequate P supply (Schaffert et al., 2001; Hufnagel et al., 2014). Two Bacillus strains, B116 and B70, belonging to the Multifunctional Microorganisms Collection from Embrapa Milho e Sorgo (Brazil), were previously isolated from the rhizosphere of P-efficient maize genotypes and characterized as P-solubilizers (Oliveira et al., 2009; Gomes et al., 2014). The strains were individually cultivated in Tryptic Soy Broth (TSB) medium under agitation at 28 ${ }^{\circ} \mathrm{C}$ for five days, centrifuged at 6,000 RPM for 10 minutes and the bacterial suspensions were adjusted to absorbance equal to 1, at wavelength of $550 \mathrm{~nm}$, in order to obtain approximately $10^{8}$ cells $\mathrm{mL}^{-1}$. Bacterial suspensions were prepared in a charcoal carrier based formulation, in the proportion of $30 \%(\mathrm{w} / \mathrm{v})$ of total liquid inoculant
(500 mL inoculant $\mathrm{ha}^{-1}$ ), constituting a final concentration of about $10^{7}$ cells per gram of seed. Then, the inoculant (bacteria + charcoal) was applied as seed coat with $5 \%(\mathrm{w} / \mathrm{w})$ cassava starch gum as adhesive and the coated seed was left to dry in the shade for $30 \mathrm{~min}$ and then used for sowing.

\section{Greenhouse experiment}

For the greenhouse experiment, 12 treatments were arranged in a completely randomized design, with four replications. The treatments consisted of a $2 \times 2 \times 3$ factorial arrangement, with the factors being two sorghum genotypes (BR007 and SC283), two sources of $\mathrm{P}$ [RP and the mixture of half dose of TSP and another half of RP $(1 / 2 \mathrm{TSP}+1 / 2 \mathrm{RP})]$, and three inoculation treatments, B116 and B70 strains and non-inoculated control (B0) (Table 1).

Pots containing $4 \mathrm{~kg}$ of a clayey Oxisol (Typic Haplustox Brazilian savanna soil) were used, with the following chemical and physical characteristics, before the application of the inputs: $\mathrm{pH} \mathrm{H}_{2} \mathrm{O}=5.2, \mathrm{Al}=0.4, \mathrm{Ca}=2.5, \mathrm{Mg}$ $=0.2$, cation exchange capacity $(\mathrm{CEC})=11.8$ (cmolc dm $\left.{ }^{-3}\right), \mathrm{P}=2.2, \mathrm{~K}=30.3\left(\mathrm{mg} \mathrm{dm}^{-3}\right)$, base saturation $(\mathrm{V})=23.2 \%$ and clay content $=74.0$ dag $\mathrm{kg}^{-1}$. Ten days before planting, the pots were fertilized with nutrient solution without $\mathrm{P}$ (Somasegaran \& Hoben, 1985): $285.8 \mathrm{mg} \mathrm{dm}^{-3}$ $\mathrm{NH}_{4} \mathrm{NO}_{3}, 382.4 \mathrm{mg} \mathrm{dm}^{-3} \mathrm{KCl}, 123.9 \mathrm{mg} \mathrm{dm}^{-3}$ $\left(\mathrm{NH}_{4}\right)_{2} \mathrm{SO}_{4}, 2.9 \mathrm{mg} \mathrm{dm}^{-3} \mathrm{H}_{3} \mathrm{BO}_{3}, 7.9 \mathrm{mg} \mathrm{dm}^{-3}$ $\mathrm{CuSO}_{4} \cdot 5 \mathrm{H}_{2} \mathrm{O}, 9.2 \mathrm{mg} \mathrm{dm}{ }^{-3} \mathrm{MnSO}_{4} \cdot \mathrm{H}_{2} \mathrm{O}, 8.3 \mathrm{mg}$ $\mathrm{dm}^{-3} \mathrm{ZnCl}_{2}, 0.5 \mathrm{mg} \mathrm{dm}^{-3}\left(\mathrm{NH}_{4}\right)_{6} \mathrm{Mo}_{7} \mathrm{O}_{24} \cdot 4 \mathrm{H}_{2} \mathrm{O}$. 
Table 1. Treatments used to determine the effect of inoculation of phosphorus solubilizing bacteria in sorghum, under greenhouse and field conditions.

Treatment

Sorghum

Genotype

P source

Inoculant

\begin{tabular}{|c|c|c|c|}
\hline 1 & BR007 & $1 / 2 R P+1 / 2 T S P$ & \multirow{5}{*}{ B0 } \\
\hline 2 & SC283 & $1 / 2 R P+1 / 2 T S P$ & \\
\hline & & & \\
\hline 3 & BR007 & RP & \\
\hline 4 & SC283 & $\mathrm{RP}$ & \\
\hline 5 & BR007 & $1 / 2 R P+1 / 2 T S P$ & \multirow{5}{*}{ B116 } \\
\hline 6 & SC283 & $1 / 2 R P+1 / 2 T S P$ & \\
\hline & & & \\
\hline 7 & BR007 & $\mathrm{RP}$ & \\
\hline 8 & SC283 & $\mathrm{RP}$ & \\
\hline 9 & BR007 & $1 / 2 R P+1 / 2 T S P$ & \multirow{5}{*}{ B70 } \\
\hline 10 & SC283 & $1 / 2 R P+1 / 2 T S P$ & \\
\hline & & & \\
\hline 11 & BR007 & $\mathrm{RP}$ & \\
\hline 12 & SC283 & $\mathrm{RP}$ & \\
\hline 13 & BR007 & TSP & \multirow{5}{*}{ *Control } \\
\hline 14 & SC283 & TSP & \\
\hline & & & \\
\hline 15 & BR007 & No $\mathrm{P}$ added & \\
\hline 16 & SC283 & No $P$ added & \\
\hline
\end{tabular}

Triple superphosphate (TSP), Rock phosphate (RP), half dose of RP + half dose of TSP $(1 / 2 \mathrm{RP}+$ $1 / 2$ TSP), B0: non-inoculated, B116: P-solubilizing strain, B70: P-solubilizing strain. *Only in the field experiment. 
Twenty days after sowing, it was replaced by the same nutrient solution at half strength. The $\mathrm{P}$ sources were triple superphosphate (TSP) and Araxá rock phosphate (RP), both at $300 \mathrm{mg} \mathrm{P} \mathrm{dm}^{-3}$ soil, and a treatment with no $\mathrm{P}$ added. The pots were incubated for twenty days in the greenhouse, followed by planting of 20 sorghum seeds per pot, and leaving 10 plants per pot eight days after sowing. Twenty days after planting, the nutrients were reapplied with half strength nutrient solution. Seed inoculation with microorganisms was performed at planting time as described above.

After 50 days of planting, at the pre-flowering stage, the experimental plants were harvested for biomass and $\mathrm{P}$ content measurements. The plants were carefully collected from the pots, the shoot and roots separated and dried in forced air circulation oven at $65^{\circ} \mathrm{C}$ until constant weight. Dry plant tissues were then weighted, grounded and homogenized to determine root and shoot dry matter production and $\mathrm{P}$ content. Chemical analyses were conducted in the Plant Chemical Analysis Laboratory at Embrapa Maize and Sorghum, using inductively-coupled argon plasma (ICP-OES) (Nogueira \& Souza, 2005).

\section{Field experiment}

The field experiment was carried out at Embrapa Milho e Sorgo, Sete Lagoas-MG, Brazil

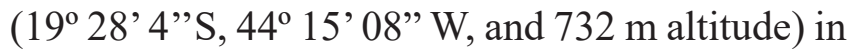
the summer of 2014.

The treatments consisted of a $2 \times 4 \times 3$ factorial arrangement, with the factors being two sorghum genotypes (BR007 and SC283), four $\mathrm{P}$ sources (no P added, RP, 1/2RP + 1/2TSP, and TSP), three inoculation treatments (B116 and B70 strains and non-inoculated control B0) with three replications, arranged in randomized block design (Table 1).

The field experiment was installed on a soil classified as a clayey Oxisol (Typic Haplustox Brazilian savanna soil) with $\mathrm{pH} \mathrm{H}_{2} \mathrm{O}$ $=6.3, \mathrm{Al}=0.01, \mathrm{Ca}=3.9, \mathrm{Mg}=0.7, \mathrm{CEC}=6.8$ $\left(\right.$ cmolc dm $\left.{ }^{-3}\right), \mathrm{P}=9.7, \mathrm{~K}=80.4\left(\mathrm{mg} \mathrm{dm}^{-3}\right), \mathrm{V}=$ $71.2 \%$, clay content $=74.0 \mathrm{dag} \mathrm{kg}^{-1}$, and organic matter $=3.47\left(\right.$ dag $\left.\mathrm{kg}^{-1}\right)$. The experimental plots consisted of four rows with $5 \mathrm{~m}$ length, and spacing of $0.70 \mathrm{~m}$ between rows, with two border rows of maize on each side of the plot. Three hundred $\mathrm{kg} \mathrm{ha}^{-1}$ of the formulation 20 00-20, $60 \mathrm{~kg} \mathrm{ha}^{-1} \mathrm{~N}$ and $60 \mathrm{~kg} \mathrm{ha}^{-1} \mathrm{~K}_{2} \mathrm{O}$ were applied at planting. Rock phosphate (RP) and the mixture of half the dose of TSP and another half of RP ( $1 / 2 R P+1 / 2$ TSP), used as P sources, were applied according to each treatment, at a dose of $100 \mathrm{~kg} \mathrm{P}_{2} \mathrm{O}_{5} \mathrm{ha}^{-1}$, except in the control without $\mathrm{P}$ addition (Table 1). Urea was side dressed, with two applications of $150 \mathrm{~kg} \mathrm{ha}^{-1}$ each, 30 and 45 days after planting. Additional cultivation practices were carried out as recommended for sorghum in the region. The experiments were irrigated when necessary and the sorghum plots were manually harvested at physiological maturity by removing and threshing the panicles. Grain yield was recorded as $\mathrm{kg} \mathrm{ha}^{-1}$, corrected to $13 \%$ moisture, and grain $\mathrm{P}$ content was determined by multiplying the 
nutrient concentration by the grain dry weight (Nogueira \& Souza, 2005).

The data were analyzed by ANOVA and the means were compared by the Scott-Knott test $(\mathrm{p} \leq 0.05)$ using SISVAR program, version 5.3 (Ferreira, 2011).

\section{Results}

\section{Greenhouse experiment}

The bacteria $\mathrm{B} 70$ and $\mathrm{B} 116$, used in the greenhouse and field experiments, were previously isolated from the rhizosphere of maize genotypes that are efficient in P use (Oliveira et al., 2009) and were later re-identified as Bacillus subtilis and Bacillus thuringiensis (Sousa et al., 2020), respectively.

In this study, P deficiency symptoms were observed, 20 to 30 days after germination, in the treatment that received only RP without bacteria inoculation in both sorghum genotypes (BR007 and SC283). These symptoms of P deficiency in sorghum are associated with the appearance of irregular stains of brown color in older leaves and reduced plant growth (Camacho et al., 2002). However, the inoculation of BR007 genotype with the $\mathrm{B} 70$ strain was able to reverse the $\mathrm{P}$ deficiency symptoms presented by the plants fertilized with RP, but this effect was not observed in SC283 genotype (not shown).

The results of the greenhouse experiments showed that only the sorghum genotype BR007 was responsive to inoculation with P-solubilizing bacteria, showing significant increase in root dry mass of plants fertilized with RP and inoculated with strain B70 (Table 2). In addition, significant increases were observed in the root dry mass of the genotype BR007 fertilized with $1 / 2 R P+1 / 2$ TSP in the treatments inoculated separately with B70 and B116 in comparison with the non-inoculated control treatment. There was also a significant positive effect on root $\mathrm{P}$ content in the BR007 genotype inoculated with B116 and fertilized with $1 / 2 R P+1 / 2$ TSP. On the other hand, no effect was observed in the SC283 genotype inoculated with B70 and B116 strains when compared to non-inoculated control treatment for both RP and $1 / 2 R P+1 / 2$ TSP fertilization.

\section{Field experiment}

After the positive effects observed in greenhouse, a field experiment was carried out to evaluate the effect of inoculation of B70 and B116 strains on sorghum plants and two types of soil phosphate fertilization. The average value of sorghum yield was statistically similar between the fertilization with rock phosphate and the mix of RP and TSP for the two genotypes. The trial under field conditions showed positive and significant effects of the inoculation on yield and grain P content after inoculation of BR007 genotype, corroborating the greenhouse results. There was a significant difference between the two genotypes, since BR007 inoculation resulted in a significant increase in grain yield of $38 \%$ and 26\%, when inoculated with B116 and B70, respectively, and 19\% (B116) and 32\% (B70) 


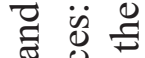

它

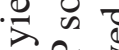

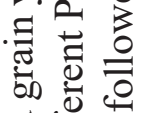

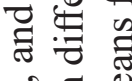

ฮิ ฏ $\sum^{\infty}$

苛完合

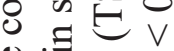

के

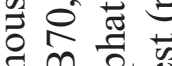

जी क्ष

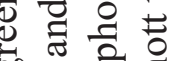

ప็

它至 苛

भै $\frac{0}{2}$

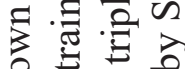

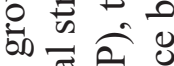

घ. 즐

卷

क्षे

क 웜

들

起语.

ठ․ㅠ क्ष

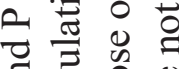

ฮี

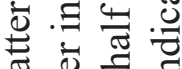

可 急

츨

읍

ज:

क ०ें

히뮤.

$\leftarrow \stackrel{\circ}{\hookrightarrow}$

웡

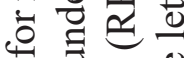

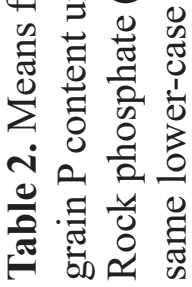

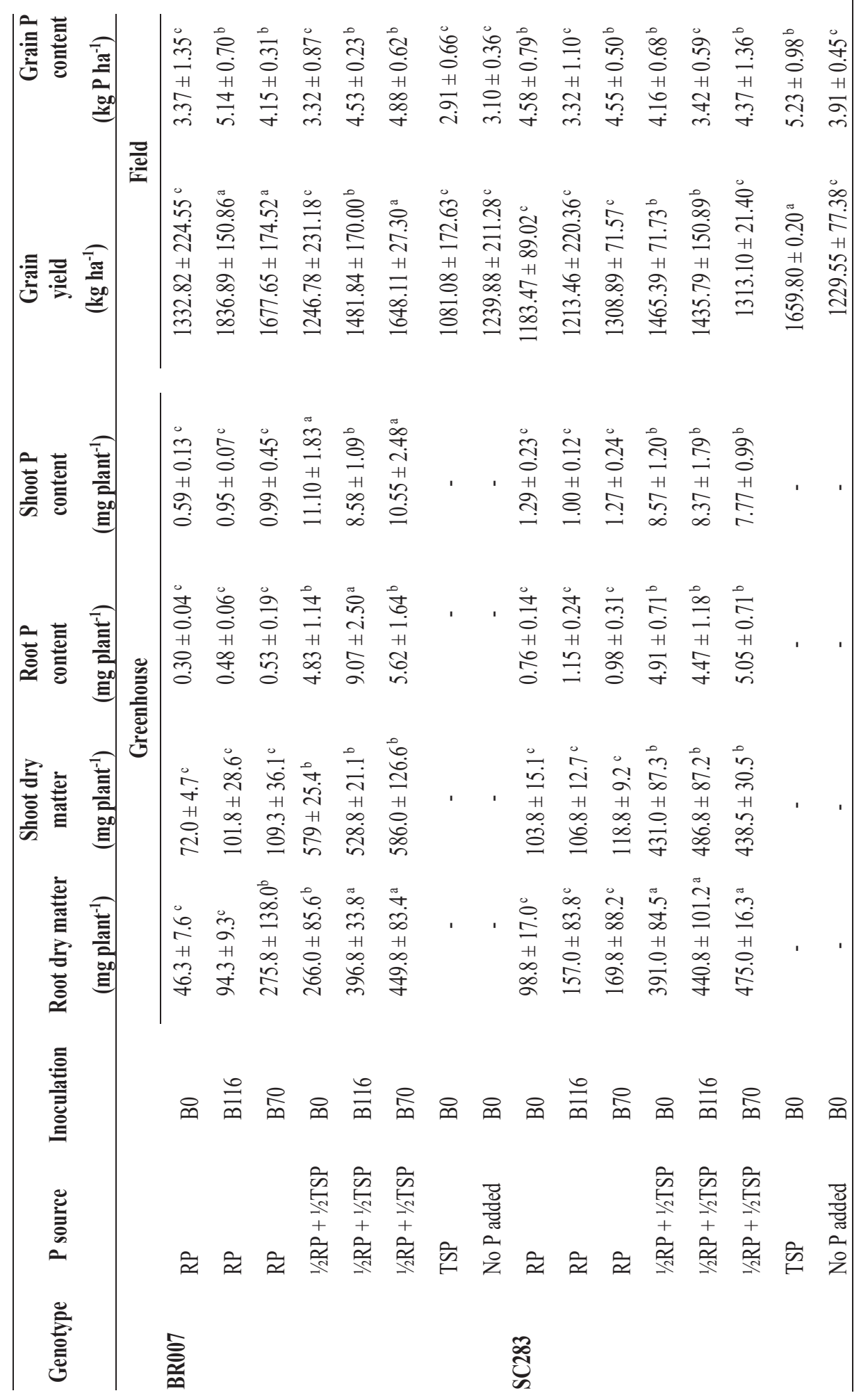


when fertilized with $1 / 2 \mathrm{RP}+1 / 2$ TSP (Table 2). A significant increase was also observed in grain $\mathrm{P}$ content of $52 \%$ (B116) and 23\% (B70) in the sorghum when fertilized with RP and 36\% (B116) and 47\% (B70) when fertilized with $1 / 2$ RP $+1 / 2$ TSP. The effect observed in yield and grain $P$ content of BR007 genotype after inoculation was related to the non-inoculated control with the same fertilization source. However, it was not possible to observe any significant increase in yield or in grain P content of the sorghum genotype SC283 when inoculated in comparison with the noninoculated, under any fertilization conditions. In general, the average values of sorghum yield were statistically similar considering the fertilization with rock phosphate and the mix of RP and TSP for the two genotypes.

\section{Discussion}

Enhancing P-efficiency through plant breeding, along with soil management practices and association with microorganisms, is essential to guarantee the sustainability and competitiveness of the agribusiness. Microorganisms can directly affect the plant ability to acquire $\mathrm{P}$ from the soil by using different mechanisms, including root system growth, mineralization of organic $\mathrm{P}$ and solubilization of precipitated phosphates in the soil (Emami et al., 2019).

In general, plant growth-promoting bacteria (PGPB) are more efficient under conditions of limited nutrient supply and depend on the interaction with other soil microorganisms and plant genotype (Ehteshami et al., 2018). These bacteria must colonize the roots and remain in the rhizosphere or in the interior of the plants in sufficient numbers to produce the beneficial effects (Ehteshami et al., 2018). In Brazil, sorghum has been cultivated as second crop after maize or soybean and they are frequently sharing the same soil. Sorghum is phylogenetically close to maize, and PGPB isolated from maize produced a remarkable effect on sorghum growth and yield. The inoculation of PGPB strains, isolated from sugarcane and inoculated in sorghum rhizosphere, significantly increased the plant biomass and decreased root diameter (Schlemper et al., 2018). Besides that, sorghum inoculation with Burkholderia tropica and Herbaspirillum frisingense seems to be genotype dependent (Schlemper et al., 2018). The results of this study corroborate both results showing that beneficial bacteria isolated from third-party host species can optimize root colonization and benefit sorghum performance, and also that inoculation responses vary according to plant genotype, bacterial strains and fertilization conditions (Schlemper et al., 2018).

The results of this study showed that only the genotype BR007 was responsive to the inoculation with P-solubilizing bacteria, with an increase in total dry mass and $\mathrm{P}$ content accumulation under controlled conditions and higher grain P content and yield in the field. Fine roots comprise most of the sorghum root system and are more prevalent in BR007 than SC283 (Hufnagel et al., 2014; Bernardino et al., 2019). 
Besides, root exudation of BR007 is greater than SC283 (Gomes et al., 2018). Considering that fine roots are sites for microorganism interactions and root exudates stimulate microorganism activity (Canarini et al., 2019), the prevalence of these traits in BR007 could have favored a stronger response to inoculation. Root exudates are essential to determine rhizosphere community. Moreover, the direct application of maize root exudates in the soil microbiota changes the population structure of bacterial species (Baudoin et al., 2003). The ability to secrete compounds into the rhizosphere is an important feature in plant roots, as approximately 5 to $21 \%$ of the photosynthetically fixed carbon is transferred to the rhizosphere through exudation, and the quantity and quality of the exudates depend on the species, plant age, and biotic and abiotic external factors (Rengel \& Marschner, 2005).

The plant-PGPB association is a complex mechanism that is influenced by the genetic background of the host plant and the bacteria strain (Vidotti et al., 2019). There are several reports in the literature that show different responses to inoculation of different plant genotypes with PGPB (Montañez et al., 2012; Yoo et al., 2016; Schlemper et al., 2018; Zeffa et al., 2019). Although the effect of the genotype on microorganism colonization is still not well known, sorghum presents differences in root exudation patterns that might influence microorganism colonization. For example, sorghum plants under P stress exudes strigolactones, which signalizes for mycorrhiza colonization, and high levels of orobanchol exudation, a type of strigolactone, may be related to higher root colonization by the microorganisms (Akiyama \& Hayashi, 2006). However, since the bacterial community that actually colonized the roots was not evaluated, it is difficult to validate if the observed differences are due to the response to inoculation, to the strain, to the additional $\mathrm{P}$ supply, or any other biotic or abiotic factor.

Another important difference observed in the results of this study was related to the fertilization with RP or combined fertilization of $1 / 2 \mathrm{RP}+1 / 2 \mathrm{TSP}$ in the soil. Considering tropical environments, in spite of the lower solubility, the application of RP as fertilizer presents some advantages, especially in the dissolution rate of these phosphates and the reaction between the mineral surface and the soil solution, which are intensified with the temperatures and humidity in tropical soils (Trabelsi et al., 2017). However, depending on the properties of RP, soil, climatic conditions, crops and management practices, up to four years of annual application are required for this phosphate to be as efficient as soluble phosphates (Ghani et al., 1994). Even with low yield due to environmental interactions, it was possible to observe significant differences among the treatments. The direct use of natural $\mathrm{P}$ sources as fertilizers is economically viable; however, especially for annual crops cultivated in soils with high adsorption and low ion exchange capacity, such as the Oxisol soil, it could be difficult to release phosphorus efficiently. Therefore, one option would be the partial substitution of the soluble fertilizers by 
the combined use with RP and the inoculation of the plants with PSB, which would increase the availability of this nutrient, reducing the costs of production. Ehteshami et al. (2018) indicate the use of soluble chemical fertilizers in some plant growth stages with high nutrient demand, such as seedling and flowering. Thus, synthetic fertilization could be combined with the use of microbial inoculants (biological fertilization), since the microorganisms may not be able to supply all the P demanded by the plant. For this, it is important to certify that the microorganisms are able to colonize the plants and are not adversely affected by the presence of soluble chemical fertilizers.

The field experiments indicate that this strategy was efficient for the sorghum genotype BR007, since the production and grain $\mathrm{P}$ content were statistically greater, considering the fertilization with RP and $1 / 2 \mathrm{RP}+1 / 2 \mathrm{TSP}$, for both inoculated bacteria and higher than the noninoculated control (Table 2). Therefore, sorghum breeding programs should take into account the $P$ use efficiency allied to the genotype-PGPB interaction as one of the parameters for the selection of the most efficient genotypes.

\section{Conclusions}

This work provides evidence that genotype was the main factor driving sorghum response to inoculation, followed by microbial strain and $\mathrm{P}$ source. Inoculation of the genotype BR007 significantly increased root biomass and $\mathrm{P}$ content under greenhouse condition, as well as yield and grain $P$ content in the field experiments. In general, the same yield was observed for sorghum cultivated in soil fertilized only with rock phosphate and in a mixture with triple phosphate. In conclusion, the use of phosphate solubilizing bacteria as bioinoculants, in combination with rock phosphate in the substitution and/or complementation of conventional P fertilization, is a promising alternative to reduce the cost and use of synthetic fertilizers. However, further investigations are essential to select the right bacterial strains that are best adapted to sorghum genotypes and that are able to solubilize P source not readily available to the plants like rock phosphate.

\section{Acknowledgments}

This work was supported by Fapemig, $\mathrm{CNPq}$ and Embrapa.

\section{Conflict of Interest}

The authors declare that they have no conflict of interest.

\section{References}

AKIYAMA, K.; HAYASHI, H. Strigolactones: chemical signals for fungal symbionts and parasitic weeds in plant roots. Annals of Botany, v. 97 , n. 6, p. 925-931, 2006. DOI: 10.1093/aob/ mcl063. 
BAUDOIN, E.; BENIZRI, E.; GUCKERT, A. Impact of artificial root exudates on the bacterial community structure in bulk soil and maize rhizosphere. Soil Biology and Biochemistry, v. 35 , n. 9, p. 1183-1192, 2003. DOI: 10.1016/ S0038-0717(03)00179-2.

BERNARDINO, K. C.; PASTINA, M. M.; MENEZES, C. B. de; SOUSA, S. M. de; MACIEL, L. S.; CARVALHO JÚNIOR, G.; GUIMARÃES, C. T.; BARROS, B. deA.; SILVA, L. da C. e; CARNEIRO, P. C. S.; SCHAFFERT, R. E.; KOCHIAN, L. V.; MAGALHÃES, J. $\mathrm{V}$. de. The genetic architecture of phosphorus efficiency in sorghum involves pleiotropic QTL for root morphology and grain yield under low phosphorus availability in the soil. BMC Plant Biology, v. 19, article 87, 2019. DOI: 10.1186/ s12870-019-1689-y.

CAMACHO, R.; MALAVOLTA, E. GUERRERO-ALVES, J.; CAMACHO, T. Vegetative growth of grain sorghum in response to phosphorus nutrition. Scientia Agricola, v. 59 , n. 4, p. 771-776, 2002. DOI: 10.1590/S010390162002000400022.

CANARINI, A.; KAISER, K.; MERCHANT, A.; RICHTER, A.; WANEK, W. Root exudation of primary metabolites: mechanisms and their roles in plant responses to environmental stimuli. Frontiers in Plant Science, v. 10, article 157, 2019. DOI: 10.3389/fpls.2019.00157.
CASA, M.; PRESSOIR, G.; BROWN, P. J.; MITCHELL, S. E.; ROONEY, W. L.; TUINSTRA, M. R.; FRANKS, C. D.; KRESOVICH, S. Community resources and strategies for association mapping in sorghum. Crop Science, v. 48, n. 1, p. 30-40, 2008. DOI: 10.2135/cropsci2007.02.0080.

EMAMI, S.; ALIKHANI, H. A.; POURBABAEI, A. A.; ETESAMI, H.; SARMADIAN, F.; MOTESSHAREZADEHET, B. Effect of rhizospheric and endophytic bacteria with multiple plant growth promoting traits on wheat growth. Environmental Science and Pollution Research, v. 26, n. 19, p. 19804-19813, 2019. DOI: 10.1007/s11356-019-05284-x.

EHTESHAMI, S. M.; KHAVAZI, K.; ASGHARZADEH, A. Forage sorghum quantity and quality as affected by biological phosphorous fertilization. Grass Forage Science, v. 73, n. 4, p. 926-937, 2018. DOI: 10.1111/gfs. 12388 .

\section{FAO. Representante da FAO Brasil apresenta} cenário da demanda por alimentos. Brasília, DF, 2017. Notícias. Available in: <http:// www.fao.org/brasil/noticias/detail-events/ en/c/901168/>. Access in: 23 Oct. 2018.

FERREIRA, D. F. Sisvar: a computer statistical analysis system. Ciência e Agrotecnologia, v. 35, n. 6, p. 1039-1042, 2011. DOI: 10.1590/ S1413-70542011000600001. 
GHANI, A.; RAJAN, S. S. S.; LEE, A. 10.1104/pp.114.243949.

Enhancement of phosphate rock solubility through biological processes. Soil Biology and Biochemistry, v. 26, n. 1, p. 127-136, 1994. DOI: 10.1016/0038-0717(94)90204-6.

GOMES, T. C.; KARAM, D.; MARINHO, C. G. S.; MARTINS, B. A. B.; SIMEONE, M. L. F.; OKUMURA, F. Ação de extratos de sorgo na germinação de sementes de milho, alface e cordade-viola (Ipomoea sp.). Revista Brasileira de Milho e Sorgo, v. 17, n. 1, p. 168-176, 2018. DOI: 10.18512/1980-6477/rbms.v17n1p168-176.

GOMES, E. A.; SILVA, U. de C.; MARRIEL, I. E.; PAIVA, C. A. O.; LANA, U. G. de P. Rock phosphate solubilizing microorganisms isolated from maize rhizosphere soil. Revista Brasileira de Milho e Sorgo, v. 13, n. 1, p. 69-81, 2014. DOI: 10.18512/1980-6477/rbms.v13n1p69-81.

HUFNAGEL, B.; SOUSA, S. M. de; ASSIS, L.; GUIMARÃES, C. T.; LEISER, W.; AZEVEDO, G. C.; NEGRI, B.; LARSON, B. G.; SHAFF, J. E.; PASTINA, M. M.; BARROS, B. A.; WELTZIEN, E.; RATTUNDE, H. F. W.; VIANA, J. H.; CLARK, R. T.; FALCÃO, A.; GAZAFFI, R.; GARCIA, A. A. F.; SCHAFFERT, R. E.; KOCHIAN, L. V.; MAGALHÃES, J. V. Duplicate and conquer: multiple homologs of PHOSPHORUS-STARVATION TOLERANCE1 enhance phosphorus acquisition and sorghum performance on low-phosphorus soils. Plant Physiology, v. 166, p. 659-677, Oct. 2014. DOI:

MAREYA, C. R.; TUGIZIMANA, F.; PIATER, L. A.; MADALA, N. E.; STEENKAMP, P. A.; DUBERY, I. A. Untargeted metabolomics reveal defensome-related metabolic reprogramming in Sorghum bicolor against infection by Burkholderia andropogonis. Metabolites, v. 9, n. 1, article 8, 2019. DOI: 10.3390/ metabo9010008.

MONTAÑEZ, A.; BLANCO, A. R.; BARLOCCO, C.; BERACOCHEA, M.; SICARDI, M. Characterization of cultivable putative endophytic plant growth promoting bacteria associated with maize cultivars (Zea mays $L$.) and their inoculation effects in vitro. Applied Soil Ecology, v. 58, p. 21-28, 2012. DOI: 10.1016/j.apsoil.2012.02.009.

NOGUEIRA, A. R. de A.; SOUZA, G. B. de (Ed.). Manual de laboratórios: solo, água, nutrição vegetal, nutrição animal e alimentos. São Carlos, SP: Embrapa Pecuária Sudeste, 2005. 334 p.

OLIVEIRA, C. A.; ALVES, V. M. C.; MARRIEL, I. E.; GOMES, E. A.; SCOTTI, M. R.; CARNEIRO, N. P.; GUIMARÃES, C. T.; SCHAFFERT, R. E.; SÁ, N. M. H. Phosphate solubilizing microorganisms isolated from rhizosphere of maize cultivated in an oxisol of the Brazilian Cerrado Biome. Soil Biology and Biochemistry, v. 41, p. 1782-1787, 2009. DOI: 
10.1016/j.soilbio.2008.01.012.

RENGEL, Z.; MARSCHNER, P. Nutrient availability and management in the rhizosphere: exploiting genotypic differences. New Phytologist, v. 168, n. 2, p. 305-312, 2005. DOI: 10.1111/j.1469-8137.2005.01558.x.

RIBEIRO, V. P.; MARRIEL, I. E.; SOUSA, S. M. de; LANA, U. G. de P.; MATTOS, B. B.; PAIVA, C. A. O.; GOMES, E. A. Endophytic Bacillus strains enhance pearl millet growth and nutrient uptake under low-P. Brazilian Journal of Microbiology, v. 49S, p. 40-46, 2018. DOI: 10.1016/j.bjm.2018.06.005.

SCHAFFERT, R. E.; ALVES, V. M. C.; PITTA, G. V. E.; BAHIA, A. F. C.; SANTOS, F. G. Genetic variability in sorghum for $\mathrm{P}$ efficiency and responsiveness. In: HORST, W. J.; SCHENK, M. K.; BURKERT, A.; CLAASSEN, N.; FLESSA, H.; FROMMER, W. B.; GOLDBACH, H.; OLFS, H. W.; ROMHELD, V.; SATTELMACHER, B.; SCHMIDHALTER, U.; SCHUBERT, S.; WIREN, N. V.; WITTENMAYER, L. (Ed.). Plant nutrition: food security and sustainability of agro-ecosystems through basic and applied research. Dordrecht: Kluwer Academic Publishers, 2001. p. 72-73.

SCHLEMPER, T. R.; DIMITROV, M. R.; GUTIERREZ, F. A. O. S.; VEEN, J. A. van; SILVEIRA, A. P. D.; KURAMAE, E. E. Effect of Burkholderia tropica and Herbaspirillum frisingense strains on sorghum growth is plant genotype dependent. PeerJ, v. 6, article e5346, 2018. DOI: $10.7717 /$ peerj.5346.

SOMASEGARAN, P.; HOBEN, H. J. Methods in legume-rhizobium technology. Honolulu: University of Hawaii at Manoa, 1985. 367 p.

SOUSA, S. M. de; OLIVEIRA, C. A.; ANDRADE, D. L.; CARVALHO, C. G. de; RIBEIRO, V. P.; PASTINA, M. M.; MARRIEL, I. E.; LANA, U. G. de P.; GOMES, E. A. Tropical Bacillus strains inoculation enhances maize root surface area, Dry weight, nutrient uptake and grain yield. Journal of Plant Growth Regulation, 2020. DOI: 10.1007/s00344-02010146-9.

STEINER, F.; LANA, M. do C.; ZOZ, T. Phosphate solubilizing fungi enhance the growth and phosphorus uptake of sorghum plants. Revista Brasileira de Milho e Sorgo, v. 15, n. 1, p. 30-38, 2016. DOI: 10.18512/1980-6477/rbms. v15n1p30-38.

TRABELSI, D.; CHERNI, A.; ZINEB, A. B.; DHANE, S. F.; MHAMDI, R. Fertilization of Phaseolus vulgaris with the Tunisian rock phosphate affects richness and structure of rhizosphere bacterial communities. Applied Soil Ecology, v. 114, p. 1-8, 2017. DOI: 10.1016/j. apsoil.2016.11.014.

VENKATESHA, M. S.; HAZRAAB, K. K.; 
GHOSH, P. K.; MISHRAD, J. P. Integrated phosphorus management in maize-chickpea rotation in moderately-alkaline Inceptisol in Kanpur, India: an agronomic and economic evaluation. Field Crops Research, v. 233, p. 2132, 2019. DOI: 10.1016/j.fcr.2019.01.001.

VIDOTTI, M. S.; MATIAS, F. I.; ALVES, F. C.; PÉREZ-RODRÍGUEZ, P.; BELTRAN, G. A.; BURGUEÑO, J.; CROSSA, J.; FRITSCHENETO, R. Maize responsiveness to Azospirillum brasilense: Insights into genetic control, heterosis and genomic prediction. Plos One, v. 14, n. 6, article e0217571, 2019. DOI: 10.1371/journal. pone. 0217571 .

WITHERS, P. J. A.; RODRIGUES, M.; SOLTANGHEISI, A.; CARVALHO, T. S. de; GUILHERME, L. R. G.; BENITES, V. de M.; GATIBONI, L.C.; SOUSA, D. M. G. de; NUNES, R. de S.; ROSOLEM, C. A.; ANDREOTE, F. D.; OLIVEIRA JÚNIOR, A. de; COUTINHO, E. L. M.; PAVINATO, P. S. Transitions to sustainable management of phosphorus in Brazilian agriculture. Scientific Reports, v. 8, article 2537, 2018. DOI: 10.1038/s41598-018-20887-z.
YOON, V.;TIAN, G.;VESSEY,J.K.; MACFIE, S. M.; DANGI, O. P.; KUMER, A. K.; TIAN, L. Colonization efficiency of different sorghum genotypes by Gluconacetobacter diazotrophicus. Plant and Soil, v. 398, n. 1/2, p. 243-256, 2016. DOI: 10.1007/s11104-015-2653-8.

ZEFFA, D. M.; PERINI, L. J.; SILVA, M. B.; SOUSA, N. V. de; SCAPIM, C. A.; OLIVEIRA, A. L. M. de; AMARAL JÚNIOR, A. T. do; AZEREDO GONÇALVES, L. S. Azospirillum brasilense promotes increases in growth and nitrogen use efficiency of maize genotypes. Plos One, v. 14, n. 4, article e0215332, 2019. DOI: 10.1371/journal.pone.0215332. 